\title{
Islam, Modernity and the Concept of Progress Islam, Pemodenan dan Konsep Kemajuan
}

\author{
Nor Farhain Zaharani, ${ }^{*}$ and Elmira Akhmetova ${ }^{* *}$
}

\begin{abstract}
This paper aims to review definitions and scope of modernity and analyze it in the context of a specific religion, Islam. The paper then highlights the harmony between progress and Islam based on the historical examples from the glorious eras of Islamic civilization in Andalusia and the Abbasid caliphate, in which modernity and religion were complementary in producing the novel innovations of that time. Knowledge creation and technological advancements were strongly pursued during that time by numerous renowned Muslim scholars, intellectuals and philosophers. This paper then examines the current situation in the Muslim world. The majority of Muslim nations are backward, impoverished and stagnant due to rigidity and restrictions in political and intellectual freedom, in addition to gender inequality and discrimination. As the paper finds, these unprecedented qualities are not a part of Islamic teachings, but the consequential effect of post colonialism and the politicization of religion by certain squatters using Islam for political interests and purposes.
\end{abstract}

Keywords: Modernity, Islam, Islamic Civilization and innovations, Muslim Spain, Abbasid Caliphate, modernity today, Islam and modernity.

\begin{abstract}
Abstrak
Penulisan ini bertujuan untuk mengulas definisi, dan skop kemodenan seta menganalisa hubungan antara modernisasi dengan agama iaitu, Islam. Terbukti pemodenan boleh wujud dengan keharmonian antara kemajuan dan Islam itu sendiri dengan mengaplikasikan contoh sejarah daripada zaman kegemilangan tamadun Islam seperti di Andalusia dan Abbasiyah dimana pemodenan dan agama saling berkait rapat antara satu sama lain untuk menghasilkan inovasi yang terbaik pada waktu itu. Penciptaan ilmu pengetahuan dan kemajuan teknologi tercetus dengan kelahiran ulama, ahli intelek dan ahli falsafah Muslim. Selain itu, bahagian berikut bagi penulisan ini mengkaji situasi masa kini di dunia Islam dimana majoriti negara Islam dikatakan mundur, dibelenggu kemiskinan dan berfikiran jumud disebabkan ketegasan dan pembata-

\footnotetext{
* Postgraduate Student, Department of History and Civilization, International Islamic University Malaysia, Email: farhain09@gmail.com.

${ }^{* *}$ Assoc. Prof. Dr, Department of History and Civilization, International Islamic University Malaysia. Email: e.akhmetova@ikiacademy.org.
} 
san didalam kebebasan berpolitik dan intelek, kesaksamaan jantina dan diskriminasi. Penulisan ini menemui, sifat sifat negatif tersebut tercetus bukan berdasarkan daripada ajaran Islam, tetapi kesan daripada pasca penjajahan dan pempolitikan berlandaskan agama daripada puak tertentu yang menggunakan Islam atas tujuan kepentingan politik.

Kata Kunci: Pemodenan, Islam, Tamadun Islam dan inovasi, Muslim Sepanyol, Khalifah Abbasiyah, kemodenan hari ini, Islam dan pemodenan.

\section{Introduction}

During the period of 700-1200 CE, Muslims experienced a glorious era of civilizational and scientific developments. Islam expanded and provided the best conditions for societal and intellectual well-being. According to Tijani Ahmad Ashimi, Islamic civilization can be portrayed as similar to an eagle pattern which had outstretched its gigantic wings. Islam expanded throughout Asia Minor, Central Asia, the Indian subcontinent, Southeast Asia, North Africa, Spain, and the Middle East. ${ }^{1}$ In addition to a massive land expansion as a political authority and religion, Muslims also dominated the fields of knowledge, including philosophy, medicine, sociology, music, geography, arts, chemistry and engineering. The most significant masterpieces created by other earlier civilizations were translated into Arabic, and then, after being enriched by the contributions of Islamic civilization, were translated into Latin. The emergence of Islam as a hub of knowledge exchange marked the turning point in the Western world, which resulted in a transformation from the Dark Ages to the eras of Renaissance and Enlightenment starting from the fourteenth century.

When Islam reached its civilizational peak, Muslim Spain and the Abbasid caliphate, and especially its capital Baghdad, were recognized as the most modernized territories in the world. However, the situation in modern times is contradictory and confusing, as modern scholarship generally demonstrates a dichotomy between religion and modernity, which simply means progress and technological innovations. Samuel Huntington, in his essay entitled The Clash of Civilizations, highlighted that culture and, mostly, religions, will be the fundamental source of conflict in the global political arena in the $21^{\text {st }}$ century. Culture here refers to belief systems, ethnicity, and language. ${ }^{2}$. Stoddard mentioned that 'Islam is in its very nature incapable of reform and progressive adaptation to the ex-

\footnotetext{
${ }^{1}$ Tijani Ahmad Ashimi, "Islamic Civilization: Factors Behind Its Glory and Decline," International Journal of Business, Economics and Law, Vol 9, 5 (2016):180.

2 Samuel P. Huntington, "The Clash of Civilizations," Foreign Affairs, Vol 72, 3 (Summer 1993):22.
} 
pansion of human knowledge'. ${ }^{3}$ This statement reflects that Muslim are unable to live with modern progression. If we observe the conditions of the Muslim nation-states today in the $21^{\text {st }}$ century, then we may also assume the same conclusions as Huntington since the most of the Muslim nations suffer from poverty, unending conflicts and wars, corruption, economic disparity, gender inequality, unemployment and terrorism. There are many cases of politicization of Islam by autocratic rulers in modern nation-states as a tool in gaining political power and accordingly such official type of religion seems to hold the nation's growth back Based on the Future of World Religion: Population Growth Projections, 2010-2050 data, Malaysia is $63.7 \%$ Muslim, and is a multiracial country ${ }^{4}$. However, can we consider Islam to be responsible for the Muslim nations' backwardness and stagnation? This paper accordingly attempts to understand the relation between Islam and modernity, as well as to explore the causes for backwardness and conflict prevailed in the modern Muslim world. The paper is divided into three main sections. The first section briefly describes the concept of modernity based on secondary literature. In the second section, based on historical facts, the paper relates Islam and modernity with progress and developments, the amalgamation of which can lead the citizens to improved lifestyles. In the past, the centers of the most advanced knowledge and innovations were in Muslim Spain, and from there, consequently it inspired Europe towards Renaissance and progress. The third section discusses the reasons for decline of the spirit of modernity in the Muslim minds by discussing the issue of politicization of Islam, which has consequently demoted the Muslims' narrative with negative values, such as extremism, conflict, antagonism, terrorism, poverty and starvation, corruption and exploitation, and hatred towards material developments.

\section{Defining Modernity and Modernism}

Orientalism and post-colonial studies generally adopted the Eurocentric approach that describes colonized nations, and their morale, culture and life-styles as backward, stagnant and underdeveloped. Edward

\footnotetext{
${ }^{3}$ Muhammad Khalid Masud, Armando Salvatore and Martin van Bruinessen, Islam and Modernity Key Issues and Debates, (Edinburgh, Edinburgh University Press, 2009), 40 ${ }^{4}$ Pew Research Centre, The Future of World Religions: Population Growth Projections, 2010-2050. Accessed 27 Novermber 2020.

http://www.globalreligiousfutures.org/countries/malaysia\#/?affiliations_religion_id=0\& affiliations_year=2010\&region_name=All\%20Countries\&restrictions_year=2016
} 
Said, a notorious scholar who developed the Orientalism discourse, described that the idea of European identity as superior in comparison with all non-European peoples and cultures, and that European hegemony considered superior over Oriental backwardness. ${ }^{5}$ Based on European standards, the benchmark for the colonized countries were set up to follow and move forward in order to become progressed and developed, that meant being 'modern'. For instance, Hussein Al Atas mentioned modernization in Malaya was brought by the British, not in science and technology but in administration, which led to the domination of Chinese immigrants in this new situation. ${ }^{6}$ Renowned scholar Muhammad Abduh suggests adopting European science so that Muslim can live by with an acceptable European ideals. ${ }^{7}$ Along with traditions and culture of the Third World nations, their religious beliefs were also seen as an obstacle to becoming modern and developed. John Stuart Mill rejected the idea that belief in God was needed to underpin morality. He believed that religion hindered the liberal and modernist progression. He stressed that people should be liberated in order to produce new way of thinking, with different ideas either in discussion or practice. ${ }^{8}$ Defining modernity and its relation to the religion, especially Islam, thus became a polemic among the scholars and politicians whether these notions of modernity and religion are in line or conflicting with one another. The main concern here is mostly related to the presence of religion in everyday life of modern Muslims and its role in the process of modernization. According to Encyclopedia Britannica, modernity is "associated with individual subjectivity, scientific explanation and rationalization, a decline emphasis of religious worldview, emergence of bureaucracy, rapid urbanization rise of nation-states and accelerated financial exchange and communication." Encyclopedia Britannica further clarifies that modernity is, "a generation who owned technological innovation, governance and socioeconomics. It conceived of one's society as engaging in organizational and knowledge advances that make one immediate predecessors appear antiquated or at least, surpassed." 10

\footnotetext{
${ }^{5}$ Edward W. Said, Orientalism, (London: Penguin Books, 1985) 7

${ }^{6}$ Syed Hussein Alatas, "Religion and Modernization in Southeast Asia", European Journal of Sociology Vol 11(2), 1970: 283

${ }^{7}$ Clinton Bennett, Muslim and Modernity (London: Continuum, 2005) 21

${ }^{8}$ Ibid, 25

9 Sharon L. Snyder, "Modernity”, Encyclopedia Britannica, accessed July 31, 2020, https://www.britannica.com/topic/modernity.

${ }^{10}$ Ibid.
} 
Newly independent nation-states in the Muslim world needed to structure and develop their own mode of modernity, including the political, economic and religious spheres, as well as social determinations. For instance, following its independence in 1924, the Republic of Turkey abolished the traditional caliphate system of governance, which has always been associated with the Islamic principles of governance and values, and was transformed into an ultra-secular country under the rule of its founder and first President, Mustafa Kemal Pasha (Ataturk, r. 19231938). Turkish political scientist E Fuat Keyman stated that Ataturk and his administration, to establish a modern and industrialized nation, initiated new policies to renovate the existence of Islamic political discourse and religious institutions into a secular-rational one. Modernity was seen as a best mechanism to be implemented in the Republic of Turkey in order to transfer the backward and traditional society into a modern and secular nation. ${ }^{11}$ The reforms adopted to secularize the educational and political structures in Turkey were in parallel with the modernization process. As Gonul Oguz stated, "It is important to note that decisions regarding these reforms were taken by a handful of elite groups, who believed that secularism was indispensable for economic development and modernization." 12 The same changes happened in other Muslim nationstates as well in the post-colonial era. Thus, in the context of the contemporary Muslim world, modernization and development simply meant Westernization and secularization, while being religious meant being backward and traditional. Hence, the main dilemma for the majority of Muslim countries is related to the question of abandoning the Islamic core values in order to progress with the Western concept of modernity, which emphasizes rationality, Westernization and secularism.

In modern scholarship, modernization is still associated with secularization process, and Western lifestyle and value systems. Indian politician Sanjay Seth, for example, defined modernity as "urbanization, a capitalist economy, the emergence of nation-states as the chief form of polity accompany with certain cultural features and modes of subjectivity." ${ }^{\prime 3}$ Subsequently, SN Eisenstadt, an Israeli sociologist, defined modernity as, "to manifest among others in growing urbanization, commodifi-

${ }^{11}$ E. Fuat Keyman. "Modernity, Secularism and Islam: The Case of Turkey," Theory, Culture \& Society 24(2), (2016): 221

12 Gonul Oguz, "Beyond Secularism: Faith, Identity, and Difference: The Turkish Case," Istanbul Universitesi Iktisat Fakultesi Mecmuasi, vol. 62 (2012): 193.

${ }^{13}$ Sanjay Seth, "Is Thinking with 'Modernity' Eurocentric?" Cultural Sociology Vol 10 (3), (2016): 390. 
cation of the economy, the development of distinctive channels of communication and agencies of education." 14 Meanwhile, modernization is a "new structural, institutional and cultural features and formations, and growing potential for social mobilization." ${ }^{15}$ Modernity accordingly leads to features which complement political, economic and social aspects, while modernization underlines a process of establishment of a capitalist economy with a democratic type of governance and modern society, which detach itself from traditions and heritage.

There is an understanding today that modernization is a part of the post-colonial propaganda and an ideology to confirm the superiority of colonial powers and the West over their previous colonies in the Third World. In fact, the most of the colonies in the Third World were of the Muslim origin by their religious culture. According to Edward Said, "Western modernity has become of universal importance"16 and people all around the world wanted to pursue the footsteps of the West to become modern and successful. In fact, Willfried Spohn, a German sociologist, stated that North Africa, the Near and Middle East, extending to Southern and Southeast Asia, started to progress in their economic, military and scientific fields under the pressure and encouragement that emerged from the colonial powers. ${ }^{17}$ Thus, the Europeans, particularly the British, French and Spanish, instigated European forms of administration to shape the local nation-building in their colonies.

While discussing the relations between modernity and the Western culture, Ali Mirsepassi-Ashtiani, an expert in Middle Eastern and Islamic studies, stated that modernization is the essence of Western culture, and, in achieving modernization, non-Western cultures and traditions are viewed as fundamentally hostile to modernity and incompatible with modernization. ${ }^{18}$ Hence, most Muslim countries have gradually abandoned their own cultural and religious values in order to achieve modernity. At the same time, modernity cannot be understood as completely opposing the cultural and religious traditions in the Muslim world thus unnecessary or even harmful for the Muslim societies. In the $19^{\text {th }}$ centu-

\footnotetext{
${ }^{14}$ SN Eisenstadt. "Modernity and Modernization," Sociopedia. isa 25, no. 1 (2010): 1.

${ }^{15}$ Ibid.

${ }^{16}$ Peter van der Veer, "The Modernity of Religion," Social History Vol 20. No 3 (1995):365

17 Willfried Spohn, "Multiple Modernity, Nationalism and Religion: A Global Perspective", Current Sociology Vol 51 (2016):277

${ }^{18}$ Ali, Mirsepassi, Intellectual Discourse and the Politics of Modernization (Cambridge: Cambridge University Press, 2000), 2.
} 
ry, a group of Muslim revivalist scholars including Rifa'a al-Tahtawi (1801-1873), Jamal al-Din Al-Afghani (1838-1897), Muhammad 'Abduh (1849-1905) and Rashid Ridha (1865-1935) were inspired from the West and perceived modernity as a way to progress in the Muslim world. Hence, modernization cannot be simply defined as a completely negative development, rather, it can be a turning point for backward societies to develop positively.

Abdul Rashid Moten argued that modernization surfaced politically prior to French Revolution (1789-1799) and economically prior to British Industrial Revolution (1760-1840). As he stated, social scientists such as David Smith and Alex Inkeles agreed that modernization is linked to Westernization. In order to achieve modernity, natives should change their traditional way of lives, value systems and practices, and move towards adopting modern Western culture. ${ }^{19}$ In sum, the Western model became a benchmark for the natives in the Third World to progress and became modern and civilized. Nonetheless, Marshall Berman, a contemporary modernist, believed that modernity unnecessarily derived from Western experiences or cultural belief. For him, modernity does not have any kind of guideline or blueprint since it spread all over the world. ${ }^{20}$ However, a few prominent figures such as Karl Marx (18181883), Emile Durkheim (1858-1917) and Weber (1864-1920) acknowledged that modernity originated in and developed from the West. ${ }^{21}$

Willfried Spohn explained that:

Modern age has its own features and consists of the emergence of nation-states, national economics, culture and societies are transformed by growing impact of economic global forces, transnational political structure. However, the revival of ethnic nationalism and religion, religion fundamentalism and religious nationalism is seen as a defensive reaction against modernity and globalization. ${ }^{2223}$

This definition of the modern age associates modernity with the emergence of modern political systems based on nation-states. Parliamentary and presidential systems, which centers on peoples' democratic rights to vote and choose an eligible leader, are first introduced in $\mathrm{Eu}-$

\footnotetext{
${ }^{19}$ Abdul Rashid Moten, "Modernity, Tradition and Modernity in Tradition in Muslim Societies," Intellectual Discourse 19, (2011):2.

${ }^{20}$ Ali Mirsepassi, Intellectual Discourse and the Politics of Modernization, 2.

${ }^{21}$ SN Eisenstadt, "Modernity and Modernization", 1.

22 Ibid.

23 Willfried Spohn, "Multiple Modernity, Nationalism and Religion: A Global Perspective,'266.
} 
rope. The nation-state system based on ethnicity and multi-ethnicity is also developed first in Europe. In addition, the nation-state system is accepted as a prerequisite to have modern political structure.

Furthermore, Spohn argues that "nationalism and national identities in modern societies are shaped by civic and secular forms." ${ }^{24}$ Religion thus becomes a private matter for citizens as the sense of nationalism is considered a new source of social cohesion to replace traditional religious bond in society. A Muslim polymath of the $14^{\text {th }}$ century, Ibn Khaldun, observed that, in a society during his time, religion was unifying factor of people under one strong cohesion. ${ }^{25}$ At present, this role is played by nationalism which is a crucial element to promote and maintain social unity within nation-states. Nationalism is a product of Western type of secular modernity which became a core force to unite the people, including in the Muslim world.

Besides, we also argue that modernity should not merely be related to physical and material developments such as high skyscraper buildings, technological advancements and economic booming, but it also involves social well-being, espousing knowledge, communal harmony and individual freedom which are all embodied under the scope of modernity. Society plays a crucial role in establishing modernization and sustaining civilizational foundations and values. Thus, the perception that modernization can eradicate local traditions and religion thus could be harmful is not always the case. It is true that the emergence of secularization and liberalization was the outcome of modernity in the Muslim world. At the same time, as the history of the Muslim intellectual thought demonstrates, the Islah and Tajdid movements were alternative strategies used by Muslim scholars throughout Islamic history to bring Muslim community back to the realities of their times by using modernization and relevantization, without renouncing Islam as an essential driving force in society and political order.

In modern era, Muslims began to realize their stagnation in the fields of politics, religious attitude, economy, science and technology after the French invasion of Egypt by Napoleon Bonaparte in 1798. The backwardness attitude in every aspect of life in a declining civilization resulted in a reform movement which was essential and a must. ${ }^{26}$ Promi-

\footnotetext{
${ }^{24}$ Ibid, 267.

${ }^{25}$ Elmira Akhmetova, "Defining Civilisation and Religion," IAIS Journal of Civilisation Studies Vol 1, Num 1(2008): 84.

${ }^{26}$ Medi Mozaffari, "Can a Declined Civilization Re-Constructed?: Islamic Civilization or Civilized Islam?,” International Relations 14(3) (1998): 14.
} 
nent figures such as Al-Afghani, Muhammad Abduh, Rashid Rida and Hasan Al-Banna initiated this reform movement which was expected to modernize the Muslim societies and also protect the Muslim world and Islamic lifestyles from stagnation. Muslim revivalists encouraged educational reforms which shall educate the Muslim masses to go beyond the traditional methods of the Quran and hadith memorizations and reciting, but to expose themselves into scientific and rational thinking methods or ijtihad. But all these changes to build a comprehensive and progressive Muslim community without detaching them from any traditional values and religious principles. Islah and tajdid consequently become a turning point for Muslims to develop their societies through modernization and concurrently ensuring the relevance of Islam to modern times. Western innovations and inspiration were welcomed as well to progress Muslim societies. In that sense, as Abdul Rashid Moten suggests, Islam and modernity do not clash; ${ }^{27}$ rather, both are equally important and their harmonious integration should be implemented. Such productive integration happened once during the Islamic Golden Age (900-1300 CE) when numerous fields of knowledge including science, mathematics, astronomy, medicine, Islamic studies and philosophy were ben cultivated by renowned scholars and philosophers, who were the best of their time both intellectually and religiously.

\section{Modernity and Islamic Civilization}

The above section suggests that the concept of modernization in a modern sense means secularization or the dismissal of religion and religion-based values from social, intellectual and political spheres in order to achieve progress and development. In fact, the process of modernization and innovations had always existed in human history when one civilization, its traditions, values and lifestyle were acknowledged by the rest as the best example to follow. During the glorious era of Islamic civilization, intellectual developments and essential innovations were all inspired by religious beliefs and ambitions, as Islam strongly encourages seeking knowledge and education. Acquired knowledge and inventions of the Muslims had spread over the world as the best inventions and life standards of that time, including in Europe. ${ }^{28}$ Thus, the originality of

\footnotetext{
27 Rashid Moten, "Modernity and Tradition and Modernity in Tradition in Muslim Societies," Intellectual Discourse 19 (2011): 12.

28 Peter O'Brien, "Islamic Civilization and (Western) Modernity," Comparative Civilization Review, 65, (Fall 2011):18.
} 
knowledge acquisition was not derived from the West to the rest only, as we experience at present; rather, the knowledge transformation and exchange of ideas existed across the continents for long centuries throughout human development.

Encyclopedia Britannica defines being modern as a generation who owned technological innovation, governance and socioeconomics. It also clearly indicates "a decline emphasis of religious worldview" as an essential element of being modern. ${ }^{29}$ Rational thinking based on secularism thus becomes the primary element of modernity according to the Western worldview. Yet, the history of the Muslims clearly demonstrate that Islamic civilization had successfully attained its modernity without neglecting its true essence, Islam, through which scientific knowledge and rationalization flourished among the religious scholars and ulama'.

In fact, this paper does not define 'civilization' as a merely material progress. According to Muhammad Hifdil Islam, the word civilization is intently related to "adab or manner and behaviors including in political, economic and social realities." ${ }^{30}$ He further added that civilization is usually associated with science and technology and goes parallel with cultural development, and it is not merely concentrated in one particular origin, but it expands through other regions or civilization. ${ }^{31}$ When civilization is experiencing progress, modernity will develop and civilization will reach its peak with inventions in technology, political stability, economics independence and enthusiastic society.

The term modern accordingly is a very subjective term without a single or absolute meaning. Rather, it's meaning, scope and attitude change over time or space. For instance, during the $9^{\text {th }}-10^{\text {th }}$ centuries, Islamic civilization was recognized as the center of transformation of knowledge between world civilizations pertaining to technological advancements, socio-religious cultural practices and politics that were based on the Shari'ah and Islamic values. Its achievements had been acknowledged and acclaimed as the most advanced civilization at that particular time where scientific and technological knowledge flourished in the Muslim land. The emergence of Islamic civilization delivered progressive human development and a better lifestyle, and its advancement

\footnotetext{
${ }^{29}$ Sharon L.Snyder, Modernity'. Accessed $27 \quad$ November 2021 https://www.britannica.com/topic/modernity

${ }^{30}$ Muhammad Hifdil Islam, "Islam and Civilization (Analysis Study on The History of Civilization in Islam,"Jurnal Al-Insyirah: Jurnal Studi Keislaman Vol 5, No 1, (2019):26-27.

31 Ibid.
} 
expanded to Europe, where the locals changed their traditional culture and norms to the ones which were fostered from the lands of Islamic civilization. The advanced knowledge of Islamic civilization had a huge impact on European civilization and consequently triggered the emergence of the Renaissance. Ezad Jamsari asserts true essence of knowledge in philosophy, science and arts in European Renaissance was a fusion from Islamic civilization. ${ }^{32}$ Barack Obama, in a speech delivered in Cairo, stated that Islamic civilization played a significant role in European civilization

As a student of history, I also know civilization's debt to Islam. It was Islam at places like Al-Azhar University, that carried the light of learning through so many centuries, paving the way for Europe's Renaissance and Enlightenment. It was innovation in Muslim communities that developed the order of algebra; our magnetic compass and tools of navigation; our mastery of pens and printing; our understanding of how disease spreads and how it can be healed. Islamic culture has given us majestic arches and soaring spires; timeless poetry and cherished music; elegant calligraphy and places of peaceful contemplation. And throughout history, Islam has demonstrated through words and deeds the possibilities of religious tolerance and racial equality. ${ }^{33}$

Moreover, in Islamic civilization, to achieve modernity and to be a civilized human being, citizens were required to be furnished with spiritual content of Islamic teachings and values. The most crucial element practiced during the glorious period of Islamic civilization was the spiritual well-being of the masses. The principles in the Quran were implemented in daily life of Muslims to achieve God's blessings and consents in accomplishing the purposes of life. Inhabitants were taught with good morale and behavior such as perseverance, patience, honesty, hard work and love of knowledge for the sake of Allah. Furthermore, Muslims are encouraged to conduct ijtihad, the process of rational thinking which is highly recommended in Islam. ${ }^{34}$ Spiritual belief and Ijtihad are the two main elements contributing to the rise of civilization without neglecting the essence of God as the Most Powerful and All-Knowing. In Islam, seeking knowledge is compulsory for every individual, as stressed in the first verse of the Surah Al-'Alaq, "Recite in the name of your Lord who

\footnotetext{
${ }^{32}$ Ezad Jamsari et al., "Ibn Firnas and His Contribution to the Aviation Technology of the World," Advances in Natural and Applied Science, 7(1):74.

33 Ibid.

${ }^{34}$ Tijani, "Islamic Civilization: Factors Behind Its Glory and Decline," 182.
} 
created." Acquisition of knowledge, either revealed knowledge as attested in the Quran, or scientific knowledge discovered by scholars, were both essential in empowering progressive process of civilization. As Burke mentioned, the Muslims were encouraged to recite and memorize the Quranic verses, and subsequently this habitual activity can lead to the cultivation of reading culture, and, accordingly, increased literacy rates, and finally enhanced knowledge advancement, specifically in the fields of science and technology, and the nurturing of intellectuals, scholars and philosophers. $^{35}$

Mehdi Mozaffari noted that Islamic civilization reached its zenith in the beginning of the $9^{\text {th }}$ century, when innovative knowledge and specialization were firmly founded by scholars and philosophers from Muslim Andalusia, Baghdad, and Morocco. During the era of the Abbasid caliphate, the caliph Al-Ma'mun (r. 813-833) initiated the construction of the largest Muslim library and the translation center of that particular time, called Bayt Al- Hikmah (House of Wisdom). ${ }^{36}$ Meanwhile, the second Umayyad caliphate in Spain had experienced a great deal of knowledge progression. Huge libraries and knowledge dissemination centers were built and owned by the Sultans who were devoted to knowledge development and scientific research. They encouraged their people to acquire knowledge and numerous scholars were persuaded to write their works. Every field of knowledge had its own prominent scholars and philosophers, namely al-Zahrawi (926-1013), Ibn Tufayl (1110-1185), Ibn Rusyd (1126-1198) and al-Baytar (1197-1248) In fact, up to the beginning of the 16th century, Muslim society was so affectionate with knowledge and philosophy, thus reading and writing of books have become a public culture. The large library was built by a wealthy Sultan in Spain, the Umayyad caliph al-Hakam (r. 961-976), which possessed about 400,000 books. Abdul Kassem, a Persian grand vizier, travelled with his library, consisting of 117,000 volumes organized in alphabetical order and carried by a caravan of four hundred camels. In view of that, Islamic civilization has become the pioneer in instituting universities, hospitals, madrasahs and libraries.

The first educational institutions, which are akin to modern universities by their structure, syllabus and method, were built in the Muslim world in the $10^{\text {th }}$ century. The university built by Fatimah Al-Fihri,

\footnotetext{
${ }^{35}$ Edmund Burke III, "Islam at the Center: Technological Complexes and the Roots of Modernity," Journal of World History, (2009):178.

${ }^{36}$ Mehdi Mozaffari, "Can a Declined Civilization be Re-constructed,"10.
} 
Al-Qarawiyyin University (857-859) located Fez Al-Azhar University in Cairo built in 972 and Nizamiyyah madrasah, founded by grand vizier Nizam-ul-Mulk in Baghdad in 1067 .. are few of them. ${ }^{37}$ Islamic civilization reached its peak and world-wide influence when the Arabic language became a lingua franca in education, international and trade relations among the political entities of both known Muslim and non-Muslim world. Hence, the Arabic successfully merged the entire civilization of the West and the East.

During the Abbasid era, movement and interaction of peoples from the East and West spread various Islamic ideologies across the Muslim lands.$^{38}$ Hence, thousands of books written by prominent scholars in Arabic were translated into European languages. Philosophy was a core subject of discussion in the intellectual discourse, and the issues that raised were not merely based on rational thinking, but they also involved religious worldview which served as a catalyst in the discussion of rational Greek philosophy. The combination of knowledge transformation, which was influenced by Hellenistic culture and ideas, and integrated with a religious worldview, made Islamic civilization distinct from other civilizations.

Knowledge exchange did not occur among Muslims alone, albeit, Christians and Jews were also welcomed in the process of discussions and decision-making. Openness towards other religions, and the amalgamation of religious knowledge with scientific knowledge, enhanced Islamic civilization to become the most comprehensive civilization of that time. Intellectual freedom was one of the key elements where the public were encouraged to think critically and creatively in innovating knowledge, without abandoning the moral principles and ethics. Bait AlHikmah was the symbol of knowledge progression. Its main focus was research and innovation, and clearly demonstrates that Islamic civilization encouraged intellectual freedom and scientific developments. ${ }^{39}$

The earlier mentioned definition by Britannica highlighted that modernity can be attained with an advanced technological development. In fact, by having educational freedom, the public could freely access education and knowledge, and consequently, innovations and technological advancement will start to develop. This was the case in Islamic civili-

\footnotetext{
${ }^{37}$ Edmund Burke III, "Islam at the Center: Technological Complexes and the Roots of Modernity," 180-182.

${ }^{38}$ Ibid, 173 .

${ }^{39}$ Tijani, "Islamic Civilization: Factors Behind Its Glory and Decline," 182.
} 
zation, as numerous prominent scholars specialized in mathematics, physics, sciences, medicine, engineering, aviation and geography emerged. Abu a- Qasim Khalaf ibn al 'Abbas al-Zahrawi (936-1013) was a renowned surgeon in Andalusia who invented surgical tools, as well as an innocuous method of removing kidney stones from the bladder. ${ }^{40}$ Another distinguished polymath was Muhammad ibn Zakariya Al-Razi (864-925), who excelled in philosophy, music, pharmacy and medicine . His substantial works on psychiatry and medical sciences such as $A l$ Thibb al-Ruhani ( The Spiritual Physick of Rhazes)and Al-Hawi fi alThibb ( The Virtous Life) were translated into Latin, and were utilized as reference and medical textbooks in European universities for centuries. The author of another medical textbook in European universities was Abu Ali Sina (980-1037), another prominent doctor who was also a chemist and philosopher. The translation of his book entitled Al-Qanun fi $a l$-Thibb (The Canon of Medicine) was used as a textbook in $\mathrm{f}$ medical science for 700 years. Another prominent scholar whose name deserve to be mentioned here is Muhammad ibn Musa al-Khwarizmi (780-850), a famous mathematician who invented the concept of zero, algorithm, and a new branch of science in the field of mathematics and algebra. Another prominent Muslim scientist was Hasan IbnAl-Haytham (965-1040), who wrote about 200 books, including 47 books on mathematics and 58 books on engineering. He also invented optic instruments and the concept of rainbow in camera lens. ${ }^{41}$ Abu al-Qasim Abbas Ibn Firnas (810-887), a scientist and faqih from Andalusia has been recognized as the father of aviation, as he discovered the principles of aviation, and invented a device called the ornithopter, which is crucial for aircraft stability during landing. His theory was fully adopted and utilized by the later scientists in innovating new technology which is compatible with modern method of flying. ${ }^{42}$

These inventions and discoveries were inspired by the spirit of Islam as Muslim scholars befitted the religious knowledge in tandem with human abilities which subsequently resulted in rational thinking. Their enthusiasm in seeking knowledge ultimately strengthened their faith. In sum, Islam was not a hindrance in the way of being the most advanced society of that time, and thus being defined modern for that particular

\footnotetext{
${ }^{40}$ Fachri Aidulsyah, "The Paradigm of Quran as the Main Element of Islamic Civilization", Tsaqafah, Vol 16, 1 (2020):139.

${ }^{41}$ Ibid, 139-140.

${ }^{42}$ Ezad Jamsari et al, "Ibn Firnas and His Contribution,” 74.
} 
time. Rather, it was a significant contributing factor to being the most advanced. The Quran has served as the source of inspiration for Muslims in acquiring scientific knowledge, which is one of the key ingredients in modernity and progress.

Another important feature of Islamic civilization was its openness and inclusivity as followers of other religious and ethnic backgrounds were all welcomed, particularly in Andalusia, Sicily, Baghdad and later in Istanbul as political capitals and civilizational centers. Citizens of other faiths were free to enjoy their individual rights to work, study and practice their own religions. In Andalusia during the Umayyad caliphate, for example, the city of Cordova had a magnificent surrounding where the three monotheistic religions existed side by side. A horn was blown from the synagogue, a bell was tingling from the church, and an adhan, the call of prayer came from the mosque, indicating that religious diversity and ethnic pluralism were accepted and most welcomed. Intermarriages between different races were also practiced, showing that there was no ethnic discrimination, superiority or racism in Muslim ruled lands. Furthermore, all ethnicities had an equal opportunity to hold any political or administrative position, dismantling feelings of prejudice or elements of racism. In one situation in Andalusia, Ismail Ibn Nagrilla, a Jew, was appointed as a vizier in Granada in the $11^{\text {th }}$ century. He also served as a successful military leader. As a leader of the Jewish community in Granada, he rebuilt a castle for the Jews to settle in during the fall of the caliphate. ${ }^{43}$ Hence, the facts from the Muslim history reveal that Islamic teachings do not oppose modernization and social inclusiveness. Rather, Islam provides a framework to create a conducive environment for inventions, innovation and knowledge production in various fields and disciplines. As we have seen, Islamic civilization has focused on both physical and spiritual developments in nurturing humankind and constructing a desirable atmosphere for wellbeing of entire community, regardless of religious and ethnic backgrounds.

Islamic civilization indirectly disseminate Islamic teachings, norms and values. Non-Muslim communities began to adopt and assimilate themselves within Islamic culture in their lifestyles such as dressing style, maintaining cleanliness and hygiene, which consequently changed the traditional culture of Jews and Christians, including in Europe. In

\footnotetext{
${ }^{43}$ Maria Rosa Menocal, "Culture in the Time of Tolerance: Al-Andalus as a Model of Our Time," Occasional Papers (2000):9.
} 
Andalusia, a culture of hygiene was popularized by the Muslims, and thousands of bathhouses built during the Muslim rule there. Public bath or hammam culture was very significant in the context of social, recreational and cultural functions. After the Reconquista, Christians began to follow this culture, especially after it became common among the royal families. ${ }^{44}$ Another Muslim culture that had been adopted in Europe was city planning, and, in this particular case, Cordova was recognized as the most modern city in Europe at that time, with the installment of lights along the sidewalks, implying the need of lights for better vision in the night.

In sum, Islamic civilization not only provided the best lifestyle and welfare for its inhabitants but had also contributed greatly to the development of European civilization. Due to its glory and superiority, knowledge, culture and inventions of Islamic civilization had been disseminated across the globe. As Burke has stated, "the larger the community or civilization, and the closer it was to surrounding communities, the greater its attractive power." ${ }^{\text {A5 }}$ Although Islamic civilization was established on the basis of Islamic norms and principles, its culture was gradually well-accepted by the non-Muslim communities. Islamic civilization as a symbol or model of modernization and highly developed civilization of that time, where both physical and spiritual developments were taken into account. Ironically, Muslims today have all this greatness. Despite the fact that Islam is open to modernity and innovations, it has been manipulated and politicized at present, and thus, Islam is perceived outdated and irrelevant to the current context of modernization. This issue is explored in the following section.

\section{Modernity and the Muslim World Today}

At present, the Muslim world is often associated with various immoral practices such as corruption, social injustice and inequality, abuse of power, domestic violence, extremism, autocratic leadership, religious manipulations and cronyism. The irony is the fact that all these malpractices are condemned in Islam.

In the post-colonialism era, most of Middle East and North Africa (MENA) countries suffer from political, economic, and intellectual as well as social grievances. They are often governed by corrupted and au-

\footnotetext{
${ }^{44}$ Olivia Remie Constable, To Live Like a Moor: Christian Perceptions of Muslim Identity in Medieval and Early Modern Spain (Philadelphia: University of Pennsylvania Press, 2018), 71-79.

${ }^{45}$ Burke, "Islam at the Center," 186.
} 
tocratic leaders, and their citizens experience miserable life conditions in poverty, social grievances and hopelessness.

The results of the 2020 Corruption Perception Index (CPI) reports that the top ranking countries (less-corrupted) on the list are non-Muslim countries. The ranking is based on the scorecard arranged in descending order where $100 \%$ score denotes free from any corruption, whereas 0 means highly corrupted. Denmark (87\%) and New Zealand $(87 \%)$ are in the highest position. Next on the list is Finland (86\%), followed by Singapore, Sweden and Switzerland, with the same score of $85 \%$. At the bottom of the list, indicating the most corrupted countries, are Somalia (9\%), South Sudan (12\%), Syria (13\%), and Yemen (15\%). Most of the MENA countries are at the bottom, except the UAE and Qatar, which managed to get a moderate scores of $71 \%$ and $62 \%$, respectively. ${ }^{46}$ It is apparent that the most corrupted countries are those which involved in ongoing civil wars and calamities, particularly Syria and Yemen. In the post-Arab Spring period, the citizens of these countries live in misery with inadequate supply of food and water, the communities are disunited due to weaknesses and ineffectiveness of the current political leadership.

Most of the Arab countries are governed today by the monarchy system, in which the king enjoys absolute power. It is not unusual that the monarchs are also exposed to cronyism where family members are selected to hold all the important political and administrative positions in the government without any democratic gesture from the public. Perhaps a long-term kingship with absolute power can lead the king to be despotic, brutal and dictatorial, although this is not always the case. Behind the veil of certain Arab nations, whoever opposes or criticizes the king or even rulers who are elected democratically may be executed or jailed. In modern political history, a political uprising can be orchestrated across the regions within a split second, and this is dubbed as technological revolution, where social media becomes a triggering tool for mass mobilization. Adam Smidi \& Saif Shahin elaborated that:

'Many of them emphasized the novelty of social media as a means of mass communication and how they altered the dynamics of the relationship between governments and citizens. The Arab monarchies and military dictatorships, these articles argued, had retained power for long by controlling the mass media and using them to manipulate public opinion; social media, however, took that control away from authoritari-

\footnotetext{
${ }^{46}$ Corruption Perceptions Index, Transparency International: the global coalition against corruption. Accessed on August 6 2020. https://www.transparency.org/en/cpi/2019
} 
an hands and provided a voice to the public. This fundamental change had wide-reaching effects: making citizens better informed, turning them into activists, facilitating public organization and collective action, and eventually helping the development of democratic institutions that could replace autocratic regimes.'

In the Arab regions during the Arab Spring of 2011, people revolted against their oppressive governments. It first started in Tunisia when Mohamed Bouazizi burned himself down as a sign of protest against the oppressive government when he failed to manage high cost of living. The Arab people in Libya, Syria, Tunisia and Egypt opted to change the whole governmental system, and accepted the Western type of government based on democracy since it promotes freedom of speech and establishes a legitimate government through elections and justice. However, the abrupt change in the political system created a chaos in the society as we can observe this on the example of Egypt. Mohamed Morsi Issa Al-Ayyat (r. 2012-2013) was legitimately elected as a President of Egypt by a fair democratic election. Unfortunately, after one year of rule, he was removed from his post by a military coup led by Abdel Fattah ElSisi, who became president in 2014. On the case of Egypt, the revolution destroyed the socio-economic and political fabric of the country that, "Revolution encouraged disunity, chaos, insecurity, injustice and economic collapse, in fact, destroyed and killed social harmony and people's well- being." 48

The Arab Spring torn Syria apart as well. Syria was once a prosperous country. Unfortunately, it instantly collapsed after the revolution, and the Syrians live in agony almost for a decade due to the continuous civil war, and no resolution has been achieved until today. In addition to the absence of political freedom in the Muslim nations, the well-being of the public and their safety are completely ignored by the governments. Muslim countries largely remain underdeveloped and impoverished, without the elements of modernity and progress.

Another issue faced by the Muslims today is related to the colonial mindset prevailing in the Muslim communities. Colonialism and its policies resulted in the sense of inferiority complex among the Third World nations, in which the West is regarded superior, more advanced

\footnotetext{
${ }^{47}$ Adam Smidi and Saif Shahin, " Social Media and Social Mobilisation in the Middle East”, India Quarterly, Vol 73, No 2 (2017):198

${ }^{48}$ Elmira Akhmetova, "The Arab Spring, Good Governance and Citizens' Rights," Islam and Civilisational Renewal Vol 5, 3 (2014):334.
} 
and the best example to follow for other nations. This inferiority complex mindset impeded the natives from transformation and progress as they maintained in the same circle, and were not brave enough to step up outside the box to progress substantively. For instance, the majority of the Muslim nations are trapped in the colonial education system, and they glorify and adore any form of knowledge or ideology originated from the West. In Malaysia, there is a policy that imposes the teaching of sciences and mathematics in English in national schools. It is assumed that students can only excel if they are exposed to scientific knowledge in English alone. After a few years of execution, however, this policy totally failed because the majority of students, particularly the Malays, were found not only to be weak in English, but also in science and mathematics. Thus, this policy was terminated.

The situation is getting more complex, as religion has been manipulated and politicized by certain Muslim groups who attempted to correlate the relationship between modernity and Islam. Islamic teachings have been politicized and reinterpreted to suit the need of this radical group, even though the practices are distorting and misleading. These groups have been given various labels such as radical, conservatism, fundamentalist, extremist, liberalist and terrorist, and they are bickering about Islamic law, principles and values which seem to be in contradiction with the concept of modernity as perceived today.

Another issue in the Muslim world that needs to be addressed is related to social inequality and gender-based discriminations. Gender segregation is one of the crucial problems in the MENA countries which follow the patriarchal socio-political systems with male domination in politics, education and workplace, while women have limited rights in all of these spheres. According to Gole, "Women are defined as a young girl, wife, mother who compulsory to adhere to their chastity and permissible act in the religion." 49

Women have equal rights to publish, study, work, speak in parliament and to become involved in general elections, ${ }^{50}$ and, most importantly, these rights are in line with the Qur'anic teachings. According to the traditional expectations, however, a woman is supposed to remain at home and duly obey her parents or a spouse. It is true that the position of women in the many current Muslim societies has fundamentally

49 Nilufer, Gole, "Snapshots of Islamic Modernities," Daedalus, 129,1 (Winter 2000):99.

${ }^{50}$ Ibid. 
changed. But many women in Middle Eastern, Asian and African countries are deprived from receiving proper education or rights to work. Gender inequality and discriminations create a huge communal gap in the Muslim world. Nezahat Kucuk stated that:

The main reason behind low level of female participation in labor force caused by cultural value where women should staying at home rather than working considered a symbol of prestige in MENA countries. According to Gender Inequality Index, Tunisia with a Muslim population ratio of $97 \%$ has a GII of 0.515 , while Afghanistan with a similar Muslim population ratio (98\%) has a much worse gender equality, with a GII value of 0.797 . It is believed, the factors comprise of cultural, religious, socioeconomic, legal and political components. ${ }^{51}$

Furthermore, the male domination in Arab culture has to do with their customs that prefer autocratic governmental system. In the economic sector, the Arab region as a major export of oil and gas, are all dominated by men, and women are discouraged to become involved in the labor market ${ }^{52}$ or own business; thus, they gradually became dependent on male population economically.

In fact, the status of women in the Muslim society is considered one of the main issues in defining the relationship between religion and modernity. There is an ongoing public debate in Muslim societies on whether women working outside the home is permissible and if so, what conditions should be provided to protect chastity and modesty of women according to the Islamic values. Gole suggests that there is an emergence of Muslim middle class who are concerned on the involvement of women in social presence, upward social mobility, service and communication sectors. ${ }^{53}$ Other issues related to women and modernity are gender segregation and veiling. Interference of women in mass media, fashion shows, and their presence in public spaces such as educational institutions, public transportation, sports and recreation, art and culture create sociocultural boundaries between women and modernity. ${ }^{54}$ These instances, which are similar to Western lifestyle, is claimed to be a contamination of Islamic teaching and values. ${ }^{55}$ Nevertheless, the deprivation of Mus-

\footnotetext{
${ }^{51}$ Nezahat Kucuk Dogan, "Gender Inequality in Muslim Majority Countries: Myth versus Facts,"Acta Oeconomica 66 (2016):214.

52 Ibid, 216.

${ }^{53}$ Nilufer Gole, "Snapshots of Islamic Modernities," 110.

${ }^{53}$ Ibid

${ }^{54}$ Ibid, 111.

55 Ibid.
} 
lim women from modern lifestyle, while practicing obvious gender inequalities and discriminations demonstrates Muslim world's attitude towards modernity. ${ }^{56}$

Outside of the MENA countries, segregation, domestic abuse and gender-based discriminations are present in other Muslim countries, such as Pakistan, Afghanistan and Iran. Such public attitude and abuse of human rights blocks the growth and development of any nation as it fails to provide well-being and security to its all citizens. Gole thus stated that the "difference and the maintenance of boundaries may lead to rejection of modernity and the establishment of autocratic regimes." 57 It seems that the main problems existing in the Muslim world are related to the absence of good governance as most of the Muslim countries are governed by autocratic political and social structures which emphasize on patriarchal and male-dominated society.

Hence, modernity as a political and social conditions is difficult to be achieved when even the fundamental rights of citizens are denied, and female half of the population is discriminated due to gender inequality widely practiced in traditional Muslim societies. As noted by Nezahat Kucuk, "the status of women in Muslim countries is inferior compared to non-Muslim countries and the only reason for this result is the democratic deficit in these countries." 58 Ironically, such attitude prevailed in the modern Muslim societies is not a part of Islamic teachings as Islam as a religion and culture never imposed certain preference based on race, gender or ethnicity. Throughout Muslim history, the women were highly educated and played significant roles in arts, science, and educational and intellectual sectors. In Andalusia, for example, women were actively engaged in political, economic and administrative matters. Sabihah (940999), the wife of caliph Al-Hakam (r. 961-976), was involved in economic matters and abolished the tax system, thus earned the public respect and compassion. ${ }^{59}$ Another Andalusian woman, Fatimah Yahya bin Yusuf al Maghami (d. 319H), who was an expert in religious knowledge, collaborated with male scholars to discuss and resolve many religious and fiqhi issues. ${ }^{60}$ The practice of gender-based discrimination is accord-

\footnotetext{
${ }^{56}$ Ibid, 112.

${ }^{57}$ Ibid, 114.

${ }^{58}$ Nezahat, "Gender Inequality in Muslim Countries,"215.

${ }^{59}$ Roziah Sidik, Mat Sidek, Izziah Suryani Arshad \& Kaseh Abu Bakar, "The role and contribution of women in Andalusia", Australian Journal of Basic and Applied Sciences, 7(4), 2013: 324

${ }^{60}$ Ibid, 326
} 
ingly not originated from Islamic teachings. Yet, due to the practice of exploitation and mistreatment of women is rampant in Muslim countries, thus Islam is viewed responsible for it and condemned as an oppressive religion towards women.

In sum, the Muslim world today is far from being modernized or serving a model for others to follow. But such condition of the Muslim world is not related to their religion or being religious. Rather, the Muslim world lacks the practice of good governance today, which is capable of providing well-being and safety for every citizen, as well as spiritual and scientific progress and advancement.

\section{Conclusion}

After studying the relation between modernity and its status in the Muslim world today, we can deduce a number of concluding points. First, there is no clash between Islam and modernity. Islamic civilization was the center of all social, technological and scientific innovations from the $7^{\text {th }}$ until $15^{\text {th }}$ centuries which can be defined being modern and the best of that time according to the modern standards.

Second, many Muslims today are living in a misery due to civil wars, widespread extremism, immorality, despotism, poverty and corruption. Yet such disadvantages are not related to the religion of Muslims; rather, Islam is a progressive religion which encourages advancement, well-being, and happiness of everyone in the society. In addition, the politicization of Islam also damaged the image of Islam in the modern world. The Muslim world is lacking modernity and progress, but not due to the existence of religion in their lives, rather, due to the absence of good governance and human dignity.

Third, every human being is entitled to get free access to education, safety, political freedom, and freedom of speech and occupation in order to establish a modernized nation. In the Muslim world, the public is mostly deprived from enjoying these rights due to authoritarian leadership and traditional man-centered societies. Social illnesses such as bribery, corruption, crime, domestic abuse, gender inequality and segregations, religious manipulation, and rigidity in interpreting modernity are some of the core problems encountered by Muslims today. Consequently, Muslims need a fresh interpretation of the concepts of modernity and its potential in creating better Muslim societies. Relevant interpretations of Islamic teachings are also crucial today in order to sustain the relevance of Islam as a universal religion. The paper consequently suggests that Muslim nations can achieve modernity and progress while maintaining 
being good Muslims, in parallel with Islamic teachings within the context of the true meaning of ijtihad. In sum, human-acquired knowledge and revealed knowledge should go hand in hand in achieving modernity in the context of the Islamic perspective.

Lastly, Islam promotes the fundamental rights for every human being and encourages them to live in prosperity with dignity. Due to long years of colonialism, some values and practices from the Western culture have been absorbed into the Muslim culture negatively. As a solution, positive values that are compatible with Islamic teachings can be adopted, while the counterparts must be avoided. It is also worth noting that modernity already existed within Muslim lands long before the emergence of Western superiority. What is required for Muslims today is that they restore their motivation for betterment, advancement and building of a glorious civilization.

\section{ACKNOWLEDGEMENT}

This paper was prepared with the support of the IIUM Collaborative Research Initiative Grant Scheme (C-RIGS) from International Islamic University Malaysia entitled "Construction of Moral Values Education Course Module for Pre-Service Teachers" (ID: C-RIG18-0050005).

\section{BIBLIOGRAPHY}

Akhmetova, Elmira. "The Arab Spring, Good Governance and Citizens' Rights." Islam and Civilisational Renewal Vol 5, 3 ( 2014):334-350

Akhmetova. Elmira, "Defining Civilisation and Religion," IAIS Journal of Civilisation Studies Vol 1(1) (2008):74-88

Ali Mirsepassi. Intellectual Discourse and the Politics of Modernization. Cambridge: Cambridge University Press, 2000

Bennett. C, Muslim and Modernity. London: Continuum, 2005

Brien, O. P. "Islamic Civilization and (Western) Modernity." Comparative Civilization Review, 65, Fall (2011):18-32

Burke, E. "Islam at the Center: Technological Complexes and the Roots of Modernity." Journal of World History, Vol 20, No.2 (2009):165-186 
Constable, R. O. To Live Like a Moor: Christian Perceptions of Muslim Identity in Medieval and Early Modern Spain. Philadelphia: University of Pennsylvania Press, 2018

Corruption Perceptions Index, Transparency International: the global coalition against corruption. Accessed on August 62020. https://www.transparency.org/en/cpi/2019

Dogan, Nezahat. "Gender Inequality in Muslim Majority Countries: Myth versus Facts." Acta Oeconomica 66, No 2 (2016):213-231

Eisenstadt. S.N. "Modernity and Modernization," Sociopedia 25(1)(2010):1-15

Ezad Azraai Jamsari, Mohd Aliff Mohd Nawi, Adibah Sulaiman, Roziah Sidik, Zanizam Zaidi, Mohamad Zulfazdlee Abul Hassan Ashari. "Ibn Firnas and His Contribution to the Aviation Technology of the World." Advances in Natural and Applied Sciences, 7(1), (2013):74-78

Fachri Aidulsyah. "The Paradigm of Quran as the Main Element of Islamic Civilization." Tsaqafah, Vol 16, No 1 (May 2020):127-146

Gole, N. "Snapshots of Islamic Modernities." Daedalus 129, 1 (Winter 2000):91-117

Huntington, S. “The Clash of Civilization?" Foreign Affairs, Vol 72, No. 3 (Summer 1993):22-49

Keyman. E. F. "Modernity, Secularism and Islam: The Case of Turkey," Theory, Culture \& Society 24(2) (2016):215-234

Khalid, Masud, Salvatore. A.B, V. M, Islam and Modernity Key Issues and Debates. Edinburgh: Edinburgh University Press, 2009

Menocal, R. M. "Culture in the Time of Tolerance: Al-Andalus as a Model for Our Time.” (2000):1-11

Moten, Abdul Rashid. "Modernity, Tradition and Modernity in Tradition in Muslim Societies." Intellectual Discourse, 19, 1 (2011):1-13 
Mozaffari, Mehdi. "Can a Declined Civilization be Re-Constructed?" International Relations 14, No 3 (1998):31-50

Muhammad Hifdil Islam. "Islam and Civilization (Analysis Study on the History of Civilization in Islam." Jurnal Al-Insyirah: Jurnal Studi Keislaman, Vol 5, No 1 (2019):22-39

Oguz, Gonul. "Beyond Secularism: Faith, Identity, and Difference: The Turkish Case," Istanbul Universitesi Iktis Fakultesi Mecmuasi, vol 62 (2012): 191-214

Pew-Templeton Global Religious Futures Project. Accessed 26 November 2011.

http://www.globalreligiousfutures.org/countries/malaysia\#/?affiliations_r eli-

gion_id $=0 \&$ affiliations_year $=2010 \&$ region_name $=$ All $\% 20$ Countries\&re strictions_year $=2016$

Roziah Sidek, Mat Sidek, Izziah Suryani Arshad \& Kaseh Abu Bakar, "The Role and Contribution of Women in Andalusian Muslim Civilization', Australian Journal of Basic and Applied Sciences 7(4): 323-327

Said. E, Orientalism. London: Penguin Books, 1985

Seth, S. "Is Thinking with 'Modernity' Eurocentric?," Cultural Sociology Vol 10(3) (2016):385-398

Sharon, L.S . "Modernity." Encyclopedia Britannica. Accessed July 31, 2020._https://www.britannica.com/topic/modernity

Smidi. A \& Shahin. S, "Social Media and Social Mobilisation in the Middle East", India Quarterly, Vol 73, No 2 (2017):196-209

Syed Hussein Alatas, "Religion and Modernization in Southeast Asia", European Journal of Sociology Vol 11(2) (1970):265-296

Tijani Ahmad Ashimi. "Islamic Civilization: Factors behind Its Glory and Decline." International Journal of Business, Economics and Law, Vol 9, 5 (April 2016):180-184 
Veer, P. "The Modernity of Religion," Social History Vol 20, No 3 (1995):365-371

Willfried, S. "Multiple Modernity, Nationalism and Religion: A Global

Perspective." Current Sociology Vol. 51, 3 (2003):265-286 